Massimiliano Cicoria, Ph.D. in Common Property Law

Università degli Studi di Napoli Federico II, Italy

\title{
HUMAN RIGHTS AND NEW RACIAL MEASURES IN ITALY
}

\begin{abstract}
Summary
Like great trees, human rights are rooted in the distant past. Without looking further, the red line that, connecting them, passes through the stoic principles, the patristic teachings, the class privileges, the "Costitutiones", the recognition of human value of the individual, the juridification of the concept of "person", the personality attributes, the codifications, the Universal Declaration of Human Rights and finally, the most recent views about the compensation theme, that have extended the range from material damage to non-material one. However, too frequently the winding path of human rights has been impeded or cut short by repugnant legislative measures: for example, in Italy, with the introduction in Art. 1 of Civil Code of a limitation of the legal capacity in presence of certain conditions and then, with the anti-Semitic legislation (Royal Decree Law of 5 September 1938, No. 1390, 7 September 1938, No. 1381 and December 15, 1938, No. 1779, the Royal Decree Law of 17 November 1938, No. 1728). Therefore, about 70 years after repealing of those laws, in an international populist atmosphere, we are witnessing re-introduction of legislative and administrative measures with evident racist connotation, as they create the discrimen about the enjoyment of rights between one citizen and another or, worse, between races. No European citizen may remain silent in presence of these expressions of decadence, and everyone must fight to prevent the relapse to intellectual obscurantism.
\end{abstract}

Keywords: human rights, racial laws, concept of "person", discrimination, discriminatory legislation (Decree Act. 4 October 2018 No. 113 and Decree Act 14 June 2019, No. 53)

\section{Introduction}

Long gone are the days when the Holy Scriptures admonished:

Do no wrong to a man from a strange country, and do not be hard on him; for you yourselves were living in a strange country, in the land of Egypt. ${ }^{1}$

History shows itself failing to master repugnant episodes that are travelling on the shoulders of a certain populism. The very populism that, forgetting the constitutional precepts, creates limits, walls and, above all, distinguishes between

Exodus 22, 20. And, indeed, the Pentateuch is full of warnings about the behaviors to adopt towards foreigners. In the same Exodus, for example, in the paragraph dedicated to the Decalogue, we learn that on the seventh day "you will do no work, you, your son and your daughter, your slave and your maid, your cattle, the stranger who is inside at your doors". And, again, in Leviticus it is stated that "You are to have the same law for the foreigner and the native-born." (Lev., 24, 22). We may recall an even earlier principle, the $\xi \varepsilon v i a$, that is the dedication to the guest, shown in ancient Greek culture (Iliad, VI, 230; Odyssey, XVII, pp. 481-487). 
"citizen" and "other", therefore, between those, who have been generated (were born) in a place, by condition of birth (thus, of mere luck), and those who come from an "elsewhere". And, even worse, the historical heritage is disfigured, whereby the concept of "citizen" is no longer used, being replaced by "community citizen" against a person designated as "extra-community", to emphasize the difference between a person who is born and grows up in a certain locus: the latter, which is characterized by the total elision of the legal concept of "citizen" and the preposition of the extra term, obviously understood not as "superior", but etymologically "coming from outside", from another place, arising from different roots, recalling without a shadow of a doubt the dark concept of "race".

Race: this term was coined in the zootechnical field in the XVI century in order to identify not a taxonomic ${ }^{2}$ category, but a mere animal group artificially created and belonging to domestic ${ }^{3}$ animals. The term "race" first of all harks back to the word generatio, then and perhaps more appropriately, to the ancient French haraz (i.e., horse breeding), extended in the late 1800 s to the man for ius positum ${ }^{4}$, and finally used for political purposes, with the known prevarications attributable to the fascist and National Socialist ideologies that, using the concept of the "Aryan race" - as empty as it is erroneous, detracted from and even worse, forgot the humanist theories developed gradually over time until the XIX century.

Therefore, these are the theories we have to retrace here, because "the great trees need a long time to to take root properly", and we must refer to these deep roots to eradicate even the slightest attempts at populism that lead to derailments, divisions, antitheses and, above all, to expulsions.

2 That is, a natural classification of living beings structured into smaller groups subordinated to larger groups.

3 Cavalli Sforza L. L., Cavalli Sforza F., Piazza A. Razza o pregiudizio? L'evoluzione dell'uomo fra natura e storia [Race or prejudice? The evolution of man between nature and history]. Milano, 1996, passim.

4 Rossi L. Breve storia della lingua italiana per parole [Brief history of the Italian language in words]. Loescher, v. razza, 2005.

5 Grossi P. Prima lezione di diritto [First law lesson]. Laterza, 2007, p. 22. 


\section{The profound roots of human rights}

The authorship of fundamental rights is not generally attributed to Roman law ${ }^{6}$. However, this approach cannot be shared because the lenses used by the jurist must have different graduations according to the different periods ${ }^{7}$.

Wishing, then, to limit the investigation to human dignity and freedoms, the imperial laws were relevant ${ }^{8}$.

First of all, in this sense, the work performance of the freedom in favour of the patron was forbidden, that they were contra dignitatem eius (Digesta Iustinians, 38, I, 38), or digitate [..] debeant estimari (Digesta Iustinians, 16 pr.; Paulo Sententiae, $40 \mathrm{ed}$.). In homine libero the corporis aestimatio was excluded (Digesta Iustiniani, 9, 9, I, 3). Still, the mark in front of quo facies, quae non-similartotudm pulchritudinis coelesti est figurative, minimal maculatur (Codex Theodosianus, 9, 40, 2). Moreover, the mark on the forehead was banned quo facies, quae non ad similitudinem pulchritudinis coelesti est figurata, minime maculatur (Codex Theodosianus, 9, 40, 2). Castration was considered an illicit practice not only against the slave and regardless of the adhesion of the mutilated person'; so too was prostitution. The amputation of a limb, which was previously applied as a punishment, was prohibited, as indeed the servitus poene. Finally, the institution of infamia was introduced, which was tainted by the one who, like the gladiators (Livio, in the book XXI, of the Historia, lists them qui venalem sanguinem habent), contradicted the bona mores ${ }^{10}$.

For its part, for freedom, the lex Fabia de plagiariis (of 209 BC) punished the person who had reduced a free man to the state of slavery with a death penalty; the comitial laws de provocatione (issued by $509 \mathrm{BC}$ to $44 \mathrm{BC}$ ) also aimed to defend the civis from the unjust sentences of the magistrate. With the classical legislation, the pater familias was, then, prevented from denying freedom to children through the instrument of venditio (Codex Theodosianus, 4, 8, 6 pr.); the private prison

6 Oestreich G. Geschichteder Menschenrecthe und Grundfreiheiten im UmriB [History of human rights and fundamental freedoms]. 1968. Italian translation: Storia dei diritti umani e delle libertà fondamentali, a cura di Gozzi G., traduzione di Tommasi C., Roma-Bari, 2006. The doctrine of personality rights arrives at the same conclusion. On this point, see Resta G. Autonomia privata e diritti della personalità [Private autonomy and personality rights]. Jovene, 2005, p. 18; Alpa G., Ansaldo A. Le persone fisiche, Artt. 1-10. In: Il Codice Civile Commentario [Natural persons, Articles 1-10. In: The Civil Code Commentary], P. Schlesinger (ed.), Milano, 1996, who point out that "the category of personality rights - understood in the modern sense - was born in the early seventeenth century" (p. 155); Zeno-Zencovich V. v. Personalità (diritti della) [Personality (rights of)]. In: Digesto, Sez. Civ., XIII, Torino, pp. 430, 431 Timid hints are found in Windscheid B. Diritto delle Pandette [Right of the Pandects]. Prima trad. it. a cura di Fadda C. e Bensa P. E., Utet, 1902, 633 ss.

7 The approach of Biondi B. Il diritto cristiano romano [The Roman Christian Law]. II, Milano, 1952, p. 342 is acceptable.

8 Biondi B. 1952, [The Roman Christian Law], p. 342.

$9 \quad$ Nemo liberum servum veinvitum sinentem ve castrare debet, neque quis se sponte castrandum praebere debet (1. 4, par. 2, D. de sicaris, XLVIII, 8).

10 Guarino A. Diritto privato Romano. Jovene, 1992, p. 319 [Private Roman Law]; Mazzacane A. v. Infamia (dir. rom.). In: Enc. Dir., XXI, 1971, p. 382 [Infamy (Roman Law)]. 
was forbidden (Codex Theodosianus, 9, II, I; Val. Theod. Arc. 383), nor was it possible to suffer a conviction if in codice publico solleoni inscribtionis impleta sint (Codex Theodosianus 9, 3, 4; Valentinian, 365). Finally, with Justinian, the fautor libertatis, there was a reduction in the number of cases of servitude due to the birth and imprisonment of war, as well as the abolition of senatus consulta by Claudian, reducing the woman married to a slave of others to the state of slave herself. These precepts suggest that the stoic humanitas and the patristic equality generated a precise regulation aimed at protecting the individual in many aspects, including dignity, protection of the name, physical integrity, honour and even of the home almost like a worthy antecedent of the right to privacy ${ }^{11}$.

These precepts, according to a doctrine ${ }^{12}$, were obscured in the barbaric age by the so-called Germanic right. Therefore, not even this approach appears, as far as concerned here, to be shareable. In particular, about eighty years later, the Codex Iustinianus was overshadowed by the edict of Rothari of $643,{ }^{13}$ in which the figure of the guidrigildo ("wergild") ${ }^{14}$ found its place. That is the representation of man in economic terms or, to be more precise, in monetary equivalent ${ }^{15}$. In addition to the individual assessments assigned by the successive laws ${ }^{16}$, two considerations appear relevant: the first is that the monetary evaluation of the individual stipulated in written form and no longer oral or customary precepts reduced private feuds, therefore, decreased the appeal to private justice; the second is that this economic representation, in fact already partly present in Roman law ${ }^{17}$, constituted the historical

11 On the point, see Gaudemet J. Des droits de l'homme 'ont-ils été reconnus dans l'Empire roman? [Have human rights been recognized in the Roman Empire ?] in Labeo, 1987, p. 7.

12 Calasso F. Medioevo del diritto [Middle ages of law]. I, Milano, 1954, p. 119.

13 Rothari's edict is the first Longobard legislative collection issued by King Rothari and composed of 388 articles, to which 153 chapters of the laws of Liutprando were subsequently added, 14 chapters of the laws of Ratchis and 22 chapters of the laws of Astolfo were later supplemented, setting up the code. Edictum Longobardorum. It was requisite only of the Italian population of Longobard origin (consequently, not binding to the Romans subject to Longobard rule), and it was divided into political crimes (1-14), crimes against people (15-144), crimes against things (145-152), hereditary and family law (153-226), royal rights and bonds (227-252), minor crimes (253-358) and procedure (359-388).

${ }_{14}$ From wergild, then widrigilt (wer: value; gild: money).

15 For example, Chapter 140 of the Edict states that "if a free man [..] gives poison to another, if the one who takes it is not killed by that poison, the one who gave the poison pays a compensation equal to half the value of this person, according to how much he would be assessed if he had been killed"; meanwhile, Chapter 387 specifies: "if someone, by mistake, unintentionally, were to have killeda free man, he is to make up a compensation in the measure of his esteem, and there will be no place for a feud because there was no willfulness". Chapters 11, 12 and 370 should also be read.

16 From the documents of the time it is clear that an olive grove was sold for eight pieces of currency, a child for twelve and a horse for twenty-five; likewise, cutting a horse's tail was the same price as a slave girl "with her child"!

17 The actio iniuriarum aestimatoria was envisaged, therefore the sentence in quantum aequum videbitur for any offensive injury (Guarino A. 1992, p. 986 ss.). It is hardly necessary to recall that in the XII Tables the os fractum was rewarded with a pecuniary penalty fixed in 300 axes, if the fracture was inflicted on a free person and 150 on a slave; the iniuria, on the other hand, caused a penalty of only 25 axes. 
antecedent for today's liquidation of personal damages, therefore, once again served the protection of human rights.

\section{2. (Continued) Still on the profound roots of human rights}

The guidrigildo dissipated starting from the $8^{\text {th }}$ century $\mathrm{AD}$, when this institute was supplemented by the requisition of the guilty party's assets ${ }^{18}$ : the penalty for a private person began to evolve in public. The infiltration of Roman law into the Germanic one is slow, the result of a predictable mediation of the spiritual power that from Rome comes into direct contact with the invaders ${ }^{19}$. The mediated report involves the conversion of the Barbarians to Catholicism, so the slow insinuation into their customs of the natural law precepts with the return "to the Stoic-Augustinian doctrine of the law of nature"20. The perception of the individual as being endowed with reason and dignitas for lex naturalis appeared relevant also for the purposes of fundamental rights which, in fact, gradually became established, starting from the 1900 s and up to 1200 , receiving full legitimacy ${ }^{21}$.

Legitimization penetrated into common thinking with the expansion of the "press". Throughout the fifteenth century, the tendency was to publish "works of ancient fame and canonical use"22. The ability of the individual to innovate made it clear that everyone was given the right to consult the "truth" and, therefore, the controversy was opened to Catholic matrices. The breaking point was the need to place man at the centre of the universe, to move from a humanistic - medieval vision of the individual to the Renaissance, from a casuistic or predetermined approach to a distinctly rational approach ${ }^{23}$. Thus, the juridical settings also changed: the law is based on nature in general, but in particular on human nature, and therefore on the reason of the individual. Hugo Grotius had the courage to affirm that, as founded on rationality, "natural law would remain unchanged even if we admitted, which is

18 The same, in the case of murder, would have been divided by the half to the deceased's heirs and, for the remaining part, should come from the funds of the State.

19 Suffice it to say that Rothari's Edict was written in Latin.

20 In this sense, Oestreich G. 1968 [History of human rights and fundamental freedoms], p. 23.

${ }^{21}$ Among them, three appear relevant. The first is the Constitution of Alfonso IX, whereby the rights of freedom are recognized in the Cortes del Leòn in 1181: among the aforementioned rights "the intangibility of life, honor, home and property" stands out; the second is the Constitutions of the Sicilian Kingdoms of Frederick II presented and approved by the Parliament of Melfi in 1231, wherein the puer apuliae (Frederick II) abolished, among other things, the ordeal and the duel, granted obvious powers to women, sanctioned a timely regulation of right to health and the exercise of the medical profession. Finally, the Magna Charta Libertarum signed by John Lackland in 1215 and then reduced from 63 to 47 articles, promulgated the following year by Henry III.

22 De Frede D. Ricerche per la storia della stampa e la diffusione delle idee riformate nell'Italia del Cinquecento [Research for the history of the press and the dissemination of reformed ideas in Italy of $16^{\text {th }}$ century]. Napoli, 1985, p. 21. In particular, there was the reintroduction of the works of Cicero, Livio and Seneca.

23 It is worth recalling that October 12, 1492 marks the date of the discovery of America. 
not affirmable without a great scandal, that God did not exist, or that He did not care about human affairs" 24 .

It began a few years later, at the turn of the $16^{\text {th }}$ and $17^{\text {th }}$ centuries the "philosophical liberalism" that culminated in Locke's theories, according to which men naturally would find themselves "in a state of perfect freedom to regulate their actions and to dispose of their property and persons as they see fit, within the limits of the law and of nature, without asking permission or depending on the will of another. ${ }^{25}$ In this respect, there is a clear divergence between the innateness of rights and unavailability: man transfers does not transfer the innate rights to the State, but charges the State only with protection of these rights.

The Lockean theories, as well as those of Pufendorf and the other philosophers of law were directly received by the papers of the time. The Lockean theories, as well as those of Pufendorf and the other philosophers, were directly transposed into the maps of the time. In 1679, the Habeas Corpus Act was signed; in 1689, the Bills of Rights were approved; previously, in 1627, with the Petition of Rights, the House of Commons presented a real list of personal and property rights. ${ }^{26}$ The Civil Code of Western Galicia was approved in $1797^{27}$ and the United States Declaration of Independence was signed on July 4, $1776^{28}$.

${ }^{24}$ Grotius (Huig Van Groot), in 1625, with the publication of De jure belli ac pacis, built the theory of the new construction of law based on human reason alone and for this theory he "earned" the sentence of life imprisonment in the Calvinist Netherlands. About Grotius, see Alpa G. Ugo Grozio. Qualche interrogativo di un profano [Ugo Grotius. Some questions of a profane]. Bologna, 1998.

25 Locke J. An Essay Concerning the True Original, Extent, and End of Civil Government (Italian translation - Il Secondo Trattato sul Governo, by Magri T.). Milano, 1998, p. 65.

26 The triad of just rights and liberties by Sir Edward Coke, the first supporter of Petition: personal freedom, life and property, is well known.

27 Paragraph 29 of Part I mentions "the right to the preservation of life, the right to procure things for wht is necessary, the right to ennoble one's bodily and spiritual energies, the right to defend oneself and one's possessions, the the right to assert one's good name and, finally, the right to freely regulate and manage all that is available in its entirety".

28 Suffice it to recall the second paragraph of the Declaration:

We hold these truths to be self-evident, that all men are created equal, that they are endowed by their Creator with certain unalienable Rights, that among these are Life, Liberty and the pursuit of Happiness.--That to secure these rights, Governments are instituted among Men, deriving their just powers from the consent of the governed, --That whenever any Form of Government becomes destructive of these ends, it is the Right of the People to alter or to abolish it, and to institute new Government, laying its foundation on such principles and organizing its powers in such form, as to them shall seem most likely to effect their Safety and Happiness. 
It is the era of the French revolution, therefore, of the "Declaration of the rights of man and of the citizen" 29 and above all of the less known, but very important, "Kantian philosophical devolution". ${ }^{30}$

Kant attributes a new value to man, deriving it from the ethical idea of the subject. In "Metaphysical First Principles of the Doctrine of Right", Kant points out that FREEDOM (independence from the constricting arbitrariness of another), as it can exist together with the freedom of each other according to a universal law, is this unique, original right, pertaining to every man by virtue of his humanity. ${ }^{31}$

For the philosopher, the concept of "humanity" is not, however, synonymous with mere belonging to the mankind, but instead a real "capacity" which, from a legal point of view, qualifies the subjective state of the individual. In the "Lessons of Ethics"32, Kant links the concept of humanity to those of human dignity and freedom, definitively sanctioning the principle of the unavailability of the subject: man, in particular, "can dispose of everything that belongs to his person, but not of it, and cannot use his freedom against himself" 33 . The close derivation of "humanity" from human dignity gives rise to the ethical perception of man, and constitutes the reason for the legal system to provide every useful tool to his protection: we hereby begin to glimpse the vague features of the "subjective right".

The Kantian ethical idea begins to enter law: in the second book of the "Roman Law System”, Savigny states:

29 Jellinek G. La dichiarazione dei diritti dell'uomo e del cittadino [Declaration of the Rights of Man and of the Citizen] (by Bongiovanni G.). Milano, 2002. The "Declaration" consisted of seventeen articles, whose principles all appear solemn. Among them, we recall the one referred to in Art. 1 ("Men are born and remain free and equal in rights. [..]"), in Art. 2 ("The goal of any political association is the conservation of the natural and imprescriptible rights of man. These rights are liberty, property, safety and resistance against oppression."), in Art. 4 ("Liberty consists of doing anything which does not harm others: [..]"), and in Art. 11 ("The free communication of thoughts and of opinions is one of the most precious rights of man: any citizen thus may speak, write, print freely, except to respond to the abuse of this liberty, in the cases determined by the law"). These precepts were transposed into the "Universal Declaration of Human Rights" adopted by the United Nations on 10 December 1948. On the following Declarations, see Battaglia F. v. Dichiarazioni dei diritti. In: Enc. Dir., XII. 1964, p. 409 [Declaration of Rights. In: Enc. of Law], which, in conclusion, emphasizes both the enlargement of rights from "a particular plan to a everwidening one", and on the pre-establishment, by international organizations, of instruments "aimed at protecting rights" "the highest expression of a civilization that does not want to lose its meaning and its spiritual value" (p. 421).

30 See Zatti P. Persona giuridica e soggettività. Per una definizione del concetto di persona nel rapporto con la titolarità delle situazioni soggettive [Legal Person and subjecticity. For a definition of the concept of person in relation to the ownership of subjective situations]. Cedam, 1975, p. 73.

31 Kant I. Metaphysische Anfangsgrundeder Rechtleher [Metaphysical First Principles of the Doctrine of Right], Italian translation, Primi principi metafisici della dottrina del diritto, a cura di Gonnelli F., Roma-Bari, 2005, p. 67 In the same paragraph on the innate right, the elements of the equality, of man as subject sui iuris and of man as individual iustus.

32 Kant I. Vorlesunguber Ethik [Lectures on ethics]. Menzer P. (ed.), 1924, [Italian translation, Lezioni di etica, a cura di Guerra A., Roma-Bari, 2004].

33 Kant I. 1924 [Lectures on ethics], p. 138. 
[..] every right exists because of the moral freedom inherent in each man. Therefore, the primitive concept of the person or subject of rights must coincide with the concept of man, and this primitive identity of the two concepts can be expressed by the following formula: every single man and only the individual man are capable of law $w^{34}$.

These were, therefore, the slow changes that over time led to the birth of the "aptitude to have rights, which is, the legal capacity" 35 , a bond that will link man to positive law ${ }^{36}$.

These principles were, however, diluted in the subsequent codes. Among them, the Codé civil did not say much about the capacity and the rights of the person ${ }^{37}$. Consequently, except for the Austrian General Code of $1811^{38}$, the French derivation codes and, as far as we are concerned, the pre-unification codes and the Civil Code of $1865^{39}$ will be oriented towards a purely proprietary approach: the need to protect industrial property prevailed with respect to the human person.

\section{The third subparagraph of Article 1 of the Civil Code}

The liberal principles, laboriously achieved, confusedly and tediously analysed, were completely overshadowed by the subsequent illiberal legislation. This is what happened, at least in Italy.

In the Report to the King Emperor's Majesty, the Minister of Justice Giuseppe Grandi made it clear that he had

[..] found it convenient, in harmony with the Regime's racial directives, to place in the third point of the first paragraph a provision referring to the special laws regarding the limitations on legal capacity deriving from the membership of certain races. The formula used in the text also contains a positive statement, as it establishes

34 Savigny Von F. Sistema del diritto romano attuale [Current Roman Law System]. Scialoja V. I., (ed.), Torino, 1886, II p. 2.

35 Savigny Von F. 1886, II [Current Roman Law System], p. 1.

36 Beyond these broad juridical categories, it must, on the other hand, ascribe to Savigny a clear ostracism to innate rights and, consequently, to rights of person.

37 For the relationship between the Codè Napoleon and the current Italian Civil Code, see Busnelli F. D. Il diritto delle persone[The Right of person]. In: Cinquant'anni del codice civile, Atti del Convegno di Milano [Fifty years of the Civil Code, Proceedings of the Milan Conference], 4-6 giugno 1992, Milano, 1993, p. 109.

38 In the sixteenth paragraph, it was stated that "every man has innate rights that are known by reason alone: therefore, he is to be considered a person".

39 The latter, in particular, stipulated that "any Italian enjoys civil rights" (Article 8) and that, therefore, their deprivation resulted either from the loss of citizenship (Articles 17-21) or from the so-called civil death (Articles 22-33). The principle of reciprocity was established for foreigners (Article 11). 
the principle that belonging to certain races can influence the sphere of the legal capacity of people ${ }^{40}$.

It should not be forgotten that the third paragraph of the Art. 1 of the civil code stipulated that "the limitations to the legal capacity deriving from belonging to certain races are established by special laws", that is - to enumerate them - by the legislative provisions of 1938, enacted "for the defence of the Italian race", followed by those from 1939 to 1942. In addition to the Royal Decree Law of 5 September 1938, No. 1390, 7 September 1938, No. 1381 and December 15, 1938, No. 1779, the Royal Decree Law of 17 November 1938, No. $1728^{41}$ was particularly odious. The nullity of the marriage concluded by the "Italian citizen of the Aryan race with a person belonging to another race" was stated, and it was specified in Art. 8, what criteria determined the belonging of a person to the Jewish race ${ }^{42}$. The status was to be "denounced and noted in the records of marital status and population" (Art. 9). Italian Jewish citizens could not serve in the military, exercise the office of guardian or curator except for minors or incapable of the same race, be owners or managers of companies declared attractive to national defence or companies with more than one hundred people, to own a land, a land with an estimate of more than five thousand lire or buildings with taxable income exceeding twenty thousand lire (Art. 10). Jewish parents could be deprived of parental responsibility (Art. 11). Jews could not have Aryan domestic helpers (Art. 12), nor could they be employed in the civil and military administrations of the State, in all state, provincial, municipal and controlled entities, in banks of national interest and in private insurance companies (Art. 13). The aforementioned Jews, when employed on the date of entry into force of the Royal Decree Law, were graciously "dispensed with" within three months of the same date (Art. 20). Italian citizenship of foreign Jews was automatically revoked (Art. 23) with the obligation to "leave the territory of the Kingdom, of Libya and of the Aegean possessions by 12 March 1939-XVII": penalty expulsion (Art. 24).

40 R.R. No. 18 in Pandolfelli G., Scarpello G., Stella Richter M., Dallari G. Codice Civile. Libro I, Illustrato con i lavori preparatori e con note di commento. Milano [Civil Code. Book I, Illustrated with the preparatory works and with commentary notes], 1940, p. 57 In the same Report to the King, in reference to implementation and transitory provision of Art. 106, it is stated that the denomination "Aryan race" "is not given with the purpose of defining anthropologically a determined race, but only for the criterion required by the law to clearly distinguish the Jewish race or the other extraneous races that have not merged into the race of the Italian people".

${ }^{41}$ In the Official Journal of November 29, 1938, No. 264 containing "measures for the defense of the Italian race".

42 The criteria were, as follows: both parents of Jewish nationality, or one - a Jew and the other of foreign nationality, or from Jewish mother and unknown father, and finally, a person belonging to the Jewish religion. 
What did the legal doctrine of the time of these legislative measures prescribe? Notorious pages written in 1939 by professor Francesco Degni ${ }^{43}$ remain: racial politics, according to the directives of the Grand Council of Fascism, could no longer permit that belonging to a certain race remains irrelevant as a legal element in the determination of the sphere of legal capacity of the subjects. The equality of treatment between Aryans and non-Aryans can no longer be allowed in a social organization dominated by the principle of the defence of the pure race. The influence of this principle, therefore, has led to a series of legal incapacities, enunciated in a general terms. In the Article 1 of the Civil Code that refers to special laws.

The same considerations were observed by Carlo Gangi, who, again in 1948 (therefore, after the abrogation of the racial norms), sought the ratio of discrimination in the alleged usury of the Jews. ${ }^{44} \mathrm{Messineo}^{45}$, Pugliatti ${ }^{46}$, Barassi ${ }^{47}$ appeared to reserve their criticism of the rules on the subject of discrimination. Finally, Pacchioni ${ }^{48}$ was laconic. The civil lawyers of the time, perhaps because they were obliged to, mostly did not raise criticism, supinely embracing what, conversely, was already alien to the Albertine Statute ${ }^{49}$ and to the Code of $1865^{50}$.

43 Degni F. Le persone fisiche e i diritti della personalità [The physical persons and the rights of the personality]. Torino, 1939, p. 54. In-depth studies of limitations disposed by the fascist laws permits the author to consider the historical grounds, even the Justinian and medieval law. At the same time, there is recognition of the mitigating measures tin the $16^{\text {th }}$ and $17^{\text {th }}$ centuries, and the equalization that followed the French Revolution and the Albertine Statute. Degni continued: "while in Roman imperial law and in intermediate law those incapacities were based mainly on the diversity of religion [..], in our new law they are the consequence of a rigorous and energetic racial policy, directed mainly at avoiding an excessive influence of the Jewish race in the moral and economic heritage of the Nation." (p. 52).

${ }^{44}$ Gangi C. Persone Fisiche e persone giuridiche [Physical persons and legal persons]. $2^{\text {nd }}$ ed., Milano, 1948, p. 11 ss. But see also Petrone C. L'essenza dello Stato Fascista [The essence of the Fascist State]. Roma, 1927, 66 ss. and Giurati G. v. Fascismo [Fascism]. In: Nuovo Dig. It., V. Torino, 1938, p. 953. For a proper analysis, see Alpa G. La cultura delle regole. Storia del diritto civile italiano [The culture of rules. History of Italian civil law]. Roma-Bari, 2000, p. 270 ss.

45 Messineo F. Istituzioni di diritto civile [Institutions of civil law]. Milano, 1942, developed an accurate list of criteria - not of a legal nature, but interpretative for identification of members of the Jewish race: this was due to the regulatory uncertainty of the Art. 8 Royal Legislative Decree $1728 / 1938$ cit. (p. 89, ff).

46 Pugliatti S. Gli istituti di diritto civile [Civil Law Institutes]. Vol. I, Milano, 1943, p. 131.

47 Barassi L. Istituzioni di diritto civile [Institutions of civil law]. Milano, 1944, p. 40 ss.

48 Pacchioni G. Elementi di diritto civile [Elements of civil law]. Milano, 1943, which only specified that "special laws limit the legal capacity of natural persons to belong to certain races" (p. 67).

49 Articles 24-32 sanctioned "the equality of all regalists before the law" with enjoyment of civil and political rights, admission to civil and military positions, granting of personal freedom, domicile and press, right of ownership and assembly.

50 Art. 1 attributed "to every citizen" the enjoyment of civil rights, unless he had criminal convictions; the same and without referring to the principle of reciprocity was legislated for the foreigner by Art. 3. 


\section{Article 22 of the Constitution and principle of equality}

The third paragraph of the Art. 1 of the Civil Code, as well as the measures on the subject of "defence of race" were repealed on January 20, 1944 by Royal Decree No. $25^{51}$. At the same time, the parliamentary iter began, indeed troubled, which led to the approval of the Art. 22 of the Constitution, which states that "no one can be deprived, for political reasons, of legal capacity, citizenship, name." This process, which took place before the First Subcommittee, was attended by the drafters of the calibre of La Pira, Moro, Mancini and Meuccio Ruini who, in his Report as the President of the Commission for the Constitution, had to clarify, with regard to Art. 22 that "after witnessing the arbitri who, for political or racist reasons, stripped the entire ranks of citizens of the heritage of legal capacity, citizenship, and name, it was not possible to omit an explicit prohibition".

Within the limits of the current paper, it is impossible to retrace the interesting setbacks, the constructive opinions, the individual parliamentary passages ${ }^{52}$; Here, the immediate link of legal capacity with the principle of equality should be emphasised. In particular, the same letter of the Art. 22 Cost., the Constituents' use of the adjective "none", as well as its initial provision before the Art. 3 of the Constitution and its definitive placement in Title I (civil report) of the First Part (Citizen's Rights and Duties) of the Constitution, calls for the analysis of the concept of "legal capacity" in of the context of "equality" which, enshrined in Art. 3 of the Constitution, as a logical consequence, should cause an absolute incomprehensibility, therefore, not even for political reasons $s^{53}$, of the capacity itself: the simple human quality - "humanity" or "dignity" according to the Kantian ethical approach is a sufficient requirement for the capacity. The requirement of birth, an involuntary natural fact, determines only the precise temporal moment of its

51 Royal Legislative Decree of 20 January 1944, No. 25 (Official Journal of 9 February 1944, No. 5, special series) containing "dispositions for the reintegration into the civil and political rights of Italian and foreign citizens already declared to be of Jewish race or considered of Jewish race". See also the Legislative Decree of the Lieutenant, 14 September 1944, No. 287 (Official Journal of 9 November 1944, No. 79) containing "measures relating to the reform of civil legislation". Art. 1 prescribed that Italian citizens of Jewish race were "reinstated in the full enjoyment of civil and political rights equal to those of all other citizens of whom they have equal dulie" and that "all those provisions were repealed, which, for any act or relationship, require detection or mention of race”. Declared void were the provisions for revoking citizenship (Art. 2), the annotations of a racial nature in the registers of the civil status were noted as "non-existent" (Art. 3), the exonerated employees were readmitted to the service (Art. 4) and the candidates affected by racial laws - to the competitions (Art. 5), those who had passed exams in foreign schools (Art. 6), and finally, penal procedures for violations of the racial laws dismissed and the relevant convictions revoked (Art. 7).

52 Parliamentary works can be viewed in Falzone V., Palermo F., Cosentino F. La Costituzione della Repubblica italiana illustrata con i lavori preparatori [The Constitution of the Italian Republic illustrated with the preparatory work]. Milano, 1976. Available at: www.nascitacostituzione.it [last viewed May 10, 2019].

53 In this context, see Stanzione P. Capacità, I) diritto privato. In: Enc. Giur., V, Roma, 1988, [Capacity, I) private law, in the Legal Encyclopedia, V] 4 and the references contained in Bianca C. M. Diritto Civile, 1, la norma giuridica, i soggetti [Civil Law, 1, the legal rule, the subjects]. Milano, 2002, p. 217 (nt. 6). 
acquiry: this already exists due to natural causes, as opposed to being recognized by the order, nor that it can be limited by the ius positum. It is not possible, then, to share the opinion of those who intend to treat the problem of legal capacity exclusively in terms of positive law ${ }^{54}$. There is no doubt that the major censorship to be moved to natural law is, as we known, the reference to constant, immutable, natural or supernatural principles: risk, the anachronism of the legal precept with respect to the practical need ${ }^{55}$. The negative consequences, however, linked to legal positivism, especially its modern version, are not negligible: procedural formalism

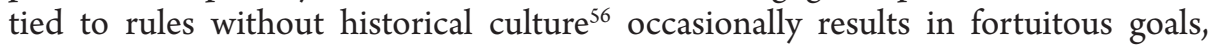
becomes capricious and transitory, and even more insidious, if the legal technique is placed in the hands of the populists.

Then and even with the benefit of the doubt, just naturalism should be preferred (perhaps Kelsenian ${ }^{57}$, therefore "structural", "fundamental" with respect to positive law) and in this perspective it must be perceived within the meaning of "capacity". It is good to consider "capacity" a prius, not a posterius of the order; not a product of law, not a fictio iuris, but the connection between man (not even, I would say, "person" according to Kelsen ${ }^{58}$, since "person" is an additional fictio iuris) and order. Hence, there is no recognition of the "capacity" on behalf of law, but instead - mere protection, inviolability of what already exists and which can neither be removed nor limited. The attribution also concerns the need to fix a dies a quo: a precise time limit within which to "connect" that subject to the right: the automatism of the attribution (coinciding with the vital birth) is not debatable. On the other hand, in addition to the aforementioned articles of the Constitution, Art. 1 of the Charter of Fundamental Rights of the European Union ("human dignity is inviolable. It must be respected and protected": therefore, not recognized) seems to testify thereof, or the subsequent Art. $21^{59}$.

Consequently, one must share the theory, according to which "the subject [..] is also a prius of the juridical order ${ }^{60}$ ", a presupposition for which "it comes to be and is

54 Stanzione P. 1988 [Capacity, I) private law, in the Legal Encyclopedia, V], p. 4.

s5 Bobbio N. Giusnaturalismo e positivismo giuridico [Legal naturalism and legal positivism]. Milano, 1965.

56 Irti N. Il salvagente della forma [The lifesaver of the form]. Roma-Bari, 2007, pp. 36-37. The lawyer masterfully emphasizes how "the rupture of the relationship between law and truth is the most painful issue in legal history. The law, separating itself from the truth, has been handed over to the relationship between the historical forces and the technical expertise of production. No one from above or from outside determines where to go anymore; and it therefore decides its own direction".

57 Kelsen H. Reine Rechtslehre. Einleitung in die rechtswissenchaftiche Problematik. Italian translation: Lineamenti di dottrina pura del diritto. [Outlines of pure doctrine of law] a cura di Treves R., Torino, 1952.

58 Ibid., p. 88.

59 "Any discrimination based on any ground such as sex, race, colour, ethnic or social origin, genetic features, language, religion or belief, political or any other opinion, membership of a national minority, property, birth, disability, age or sexual orientation shall be prohibited."

60 Barbero D. Il sistema di diritto privato [The system of private law]. $2^{\text {nd }}$ ed. a cura di Liserre e Floridia, 1993, p. 73. 
the juridical order" ${ }^{61}$ and to extend this theory also to legal capacity as a moment of connection between the subject and the order. Consequently, referring to the Art. 2 of the Constitution, it would be correct to state that "the inviolable rights of man are not already assigned by the law, but recognized as already existing". It follows that legal capacity cannot be the result of "attribution by the order [... , because it is every individual's own quality" ${ }^{62}$

\section{The new racial measures}

On October 4, 2018, Decree Law No. $113^{63}$ was approved and published in the Official Journal, legislating on the following matters: "Urgent provisions regarding international protection and immigration, public safety, as well as measures for the functionality of the Ministry of the Interior and the organization and operation of the National Agency for the administration and destination of seized and confiscated assets to organized crime". There were many conflicting points with the civil rights' system, humanitarian protection measures previously in force. Only few months after the decree came into force, it merited an intervention of the Court of Cassation. In particular, and wanting to dwell on the central data, the said provision abrogates the entire Art. 5, co. 6 d. lgs. No. 286/1998 ${ }^{64}$, which allowed, in the framework of constitutional and international obligations, to issue residence permit on the basis of humanitarian reasons. As a replacement, the Decree No. 113 introduced new typologies of "permit", first of all, for "special protection" for the duration of one year, to be granted by the territorial commissions in case of risk of persecution or torture; a residence permit in case of catastrophes was intended for calamities, to be issued, when a foreigner is not able return to his country due to an "exceptional, unanticipated catastrophy", and the temporary leave "for medical treatment" in cases where the alien has contracted "a health condition of exceptional severity"; finally and almost as a pretty concession, the new residence permit provided "for acts of particular civil value", which can be released on the advice of the Minister of the Interior.

The first problem to be examined is that the abrogated residence permit for humanitarian reasons has been introduced by the aforementioned Art. 5 in fulfilment of the civil right of asylum to the point that paragraph 4 of the said article expressly provides that "in examining the asylum application the territorial commissions evaluate for the measures referred to in Art. 5, paragraph 6, to the single consolidated

61 Barbero D. 1993 [The system of private law], p. 73.

62 Gazzoni F. Manuale di diritto privato [Manual of private law]. Napoli, 2000, p. 122. See also Bocchini F., Quadri E. Diritto private [Private law]. Torino, 2011, p. 208: "the legal capacity assumes [..] the essential profile and character of the condition of human person, of attribute that cannot be denied, for the necessary respect of the dignity of the man, whose inviolability is declared in the Art. 1 of Charter of Fundamental Rights of the European Union”.

63 The Official Journal, General Series No. 231 of 4 October 2018. The aforementioned Legislative Decree was tranformed with the law of 1 December 2018, No. 132.

64 In the Official Gazette, General Series No. 191 of 18 August 1998, Ordinary Supplement No. 139. 
text referred to in the legislative decree No. 286 of 1998, the consequences of a repatriation in light of the obligations deriving from the international conventions of which Italy is a signatory and, in particular, of Art. 3 of the European Convention for the Protection of Human Rights and Fundamental Freedoms, ratified pursuant to the law of 4 August 1955, No. 848". Here, observe the principle that even international conventions, even if ratified, act as constitutional precepts, and there is a first problem of unconstitutionality of the aforementioned Decree Law No. 113, as it stands in obvious contradiction with the Art. 117 of the Constitution, which specifies that "the legislative power is exercised by the State and by the regions in accordance with the Constitution, as well as the constraints deriving from the community order and international obligations". Moreover, this problem has become more acute than those procedures in itinere, that is, regarding those requests for permission that, formulated by foreigners before the new legislation came into force, have remained at the mercy of the waves. This is a point on which, as mentioned above, the Court of Cassation has already intervened with its judgment No. 4890 of 23 January $2019^{65}$. In particular, Ermellini, after pointing out that there is no transitional rule on the point, specifies that the current legislation "does not apply in relation to applications for recognition of a residence permit for humanitarian reasons proposed before entry into force $(5 / 10 / 2018)$ of the new law, which will therefore be scrutinized on the basis of the existing legislation at the time of their presentation". Most notably, however, is not so much the outcome of the decision, but the warning of obvious censure by the Court, which, in a passage of the sentence (page 18), states that the power to ascertain the requisites to grant new permits it has been "remodulated, in the light of significant restraints of humanitarian reasons".

In any case, Decree No. 113 appears to be censurable in other points, all of which are worse than the previous prerogatives granted to foreigners on the basis of multiple international conventions. The validity period of the current permits does not exceed two years, but six months for the one issued as a consequence of catastrophe or one year in other cases. This will entail the following consequences: the foreigner with a six-month permit will no longer be able to access the social assistance benefits provided by the Art. 41 d. lgs. No. 286/1998 for the holders of permits valid for least one year; the foreigner with a permit valid for one year will no longer have access to public housing that the Art. 42 d. lgs. No. 286/1998 guarantees to all the holders of residence permits with a duration of at least two years; again, each of the new residence permits does not provide for its holder to register with the national health service, as was the case under the current Art. $34 \mathrm{~d}$. lgs. No. 286/1998 for the permits already issued and granted due to humanitarian reasons, thereby relegating these foreigners only to access to urgent and essential outpatient or hospital medical care provided for by Art. 35 d. lgs. No. 286/1998.

These circumstances, in addition to obvious collision with the principle of Art. 3 of the Constitution, create distinctions not only between "citizen - community citizen" and "extracommunity person - foreigner", but even between "foreigner before 2018" and "foreigner after 2018", agreeing to grant certain minimum benefits

${ }^{65}$ Unpublished. 
only to the first and not to the second. This is not to mention the fact that even for foreigners before 2018 the benefits granted by the previous law will be reduced, should they intend to renew the permission already granted to them, when it expires. Here we should also note the administrative provisions, which have recently been passed and discredit the national chronicles. First of all, a reference to the "Regulation for access to subsidized social benefits" approved by the Municipality of Lodi with the resolution of the City Council No. 28/2017 - Art. 8, paragraph 5, establishes that "for the purposes of accepting the application aimed at accessing the measures and services governed by these Regulations, the income and the registered movable or immovable property governed by Art. 816 Civil Code, possibly owned abroad and not declared in Italy under the current tax law presently in force". However, bearing in mind Art. 4, paragraph 5, of the same Regulation: "in context of submitting an application for access to the measures and services governed by this Regulation, "the citizens of non-EU states must produce - even in the absence of or registered immovable or movableproperty - the certification issued by the competent authority of the external State - accompanied by a translation in Italian legalized by the Italian consular authority that certifies its conformity - made in compliance with the provisions of Art. 3 of Presidential Decree No. 445/2000 and by Art. 2 of Presidential Decree No. 394/1999 and subsequent amendments in integrations over time in place." Needless to say, this move has produced obvious discrimination among children, since for many non-EU parents it was impossible to obtain the relevant certification in the reference countries, which resulted in exclusion of children from the school canteen. And this, beyond the dutiful recourse of ordinary justice ${ }^{66}$ unpleasantly resembles the measures which, belonging to the recent past, were thought to be forgotten. Similarly, the Ordinances No. 214 of 1 July 2015 and No. 27 of 25 June 2016 issued respectively by the Mayor of the Municipality of Alassio and the Mayor of the Municipality of Carcare who, as representatives of the local communities ex Art. 50, paragraph 5, TUEL, introduced the prohibition of entry into the territory of said municipalities to migrants without an adequate health certificate attesting to the absence of infectious and transmissible diseases. Both Ordinances were declared discriminatory, and therefore unlawful, by the Genoa Tribunal in the Order of 26 July $2017^{67}$ which states, in addition to the objective impossibility on the part of all (and not only of the extra-community) of providing such a health certificate, especially the alleged factor of protection used by the mayors as the grounds for the administrative measures had been "represented both by race and ethnicity and by citizenship (different from the Italian one)": these words remind of repugnant experiences that evidently have taught little.

66 Ordinary justice imposed an order to the Municipality of Lodi to modify the said Regulation, as manifestly discriminatory, in the part of allowing the self-certification to foreigners coming from non-EU states or the adoption of the certification open to EU citizens (see Order of the Court of Milano, December 13, 2018, rg. 20954/2018, unpublished).

67 In Rep. 2017, Extra Merit, No. 2017.1956.4 
Finally, the recent security decree bis ${ }^{68}$ with Art. 1 is inserted in the "Single text of the provisions concerning the regulation of immigration and rules on the condition of foreigner", Art. 1-ter under which "The Minister of the Interior [.. ] may restrict or prohibit the entry, transit or parking of ships in the territorial sea [..] to maintain order and public safety or when the conditions referred to in Article 19, paragraph 2, letter g), limited to violations of the law on the jurisprudence of the sea [..] made in Montego Bay”. It is necessary to underline that Art. 19, in marking the cases of transit as "prejudicial to the peace, good order and security of the coastal State", indicates in the said letter g), the second paragraph, that the activity of "loading or unloading of materials, evaluates persons in violation of customs, fiscal, health or immigration laws and regulations in force in the coastal State". Needless to say, this rule had to be contemplated with the subsequent Art. 98 of the same Montego Bay Convention, which enshrined (rectius: enshrines) the obligation to provide relief to the signatory States. In particular, the first paragraph stipulates that "Each State must require that the master of a ship that flies its flag, [..]: a) provides assistance to anyone found in the sea in dangerous conditions; b) proceeds as quickly as possible to the rescue of people in danger, if he is aware of their need for help, to the extent that this initiative can reasonably be expected from him;" These rules along with the Convention ${ }^{70}$ remain in force in the Italian Republic. Thus, in a clear and incomprehensible regulatory contradiction, the State, on the one hand, requires to protect the right to life (through the rescue operations at sea), while, on the other hand, counteracts it, even placing those who violate the aforesaid prohibition under the administrative and penal sanctions according to the Art. 2 of the aforementioned security decree, bis. Additionally, the exception that already affects the first Safety decree about the evident breach of the Art. 117 of the Constitution which in its first paragraph establishes that "the legislative power is exercised by the State [..] regarding [..] the constraints arising from the Community legislation and international obligations".

68 Decree Act 14 June 2019, No. 53, defining "Urgent provisions concerning public order and security" (Official Journal, June 14, 2019, General Series No. 138).

${ }^{69}$ For the purposes of this discussion, the dictation referred to in the second paragraph of Art. 98 is also interesting: "Each coastal State promotes the establishment and permanent functioning of an adequate and effective search and rescue service to protect maritime and air security and, when circumstances require, collaborates to this end with adjacent States through regional agreements".

70 Ratified in Italy with the Law of 2 December 1994, No. 689 bearing "Ratification and execution of the United Nations Convention on the Law of the Sea, with annexes and final act, done at Montego Bay on 10 December 1982, as well as the agreement of application of Part XI of the Convention itself, with annexes, made to New York on July 29, 1994" (in the General Series No. 295 of 19.12.1994, Ordinary Supplement No. 164). 


\section{Conclusions}

\section{Natalino Irti writes:}

[..] and then how can a lawyer, who does not wish to allow an antiseptic, futile waste of his own time, nor to painfully mourn the decline, look around and fail to start the dialogue in a manner of philosophers? It is not, of course, a question of adding a few quotations or bibliographic notes - all the extrinsic and ornamental things -, but rather a personal experience of concern regarding the questions, of glimpsing the philosophical background of our working tools ${ }^{71}$.

If this is evident for the law in general, it is, as seen above, even more so for the human rights that loom as the last philosophical piece of a long, impervious path with no finish in sight. In this sense, there has been and still remains a constant "expansion" of the boundaries of fundamental rights driven by doctrine and jurisprudence, Just think about the rights of the personality present in the notes to Windscheild, the translators Fadda and Bensa included, among the various

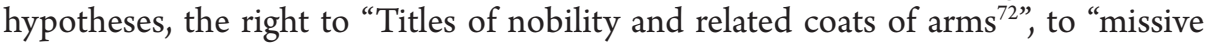
letters ${ }^{73}$ ", to "portraits ${ }^{74 "}$ : the values forgotten or modified today during a constant evolution of the times ${ }^{75}$. The same thing is said for the "right to the voice " $^{76}$ " or for the "right to the affairs ${ }^{77}$." The path taken by the right to privacy, considered nonexistent in the early $1970 \mathrm{~s}^{78}$, then definitively transformed by evolution of telecommunications, is relevant. Finally, today we are talking about the right to "sexual identity $^{79}$ ", "self-determination ${ }^{80}$ ", "information ${ }^{81}$ ", "right to fame ${ }^{82}$ " and surely in

${ }_{71}$ Irti N. Nichilismo Giuridico [Legal Nihilism]. Roma-Bari, 2005, VII.

72 Windscheid B. 1902 [Right of the Pandects], p. 647. See also De Cupis A. I diritti della personalità [The rights of the personality]. In: Trattato di dir. civ. [Civil Law Treaty], Cicu A. and Messineo F. (eds.), IV, t. 2, Milano, 1961, p. 165.

73 Windscheid B. 1902 [Right of the Pandects], p. 647; De Cupis A., 1961 [The rights of the personality. In: Civil Law Treaty], p. 165.

74 Windscheid B. 1902 [Right of the Pandects], p. 650.

75 Windscheid B. 1902 [Right of the Pandects], p. 654.

76 Degni F. Trattato di diritto civile italiano, Le persone fisiche e i diritti della personalità [Italian Civil Law Treaty, Natural persons and personality rights]. Vol. II, t. 1, Torino, 1939, which examines, however, the "right to the free performance of one's business" p. 210 ss.

77 Ligi F. Contributo allo studio comparato dei diritti della personalità negli ordinamenti: tedesco, americano, francese e italiano [Contribution to the comparative study of personality rights in the legal systems: German, American, French and Italian]. In: AnNo. dir. comp e di studi leg., III, 1956 p. 196. But, lastly, v. Resta G. 2005, pp. 167-169.

78 Ligi F. 1956 [Contribution to the comparative study of personality rights in the legal systems: German, American, French and Italian], p. 199.

79 Civil Cassation, Section I, 29 October 1963 No. 2878, in Civil Justice, 1963, I, 2520 and App. Milan, 19 January 1971, in Giur. It., I, sect. II, 1971, p. 1026.

80 Rescigno P. v. Personalità (diritti della) [Rights of personality]. In: Enc. Giur., XXIII, Roma, 1991, p. 6

81 Pinna A. Autodeterminazione e consenso: da regola per i trattamenti sanitari a principio generale [Self-determination and consent: as a rule for general principle healthcare treatments. In: contr. and business]. In: Contratto e imp., 2006, p. 589.

82 Loiodice A. v. Informazione (diritto alla) [Information (Right of)]. In: Enc. Dir., XXI, 1971, p. 472. 
the future the right to live well, the right to happiness will have relevance. And we must not leave the path we have started upon, not simply by considering rights, but by viewing the instrument of their protection. The extension by the jurisprudence ${ }^{83}$, in the Italian legislation of the requirement referred to in Article 2059 of the Civil Code $^{84}$ and therefore revealing the reimbursement of non-pecuniary damages far beyond the limits established by the law, followed up on extensive and dated doctrinaire criticisms which emphasised the need to protect all constitutionally guaranteed rights with compensation for non-material damage ${ }^{85}$.

Consequently, a certain philosophical fund, beyond the declarations of principle, cannot suffer exemptions, nor conceive limitations attributable to any process of commodification or, even worse, of damnatio memoriae. The specific weight or, better, the ethical fullness contained in the juridical or naturalistic concepts of "man", "person", "ability" and whatever else, cannot, in short, be borrowed or bartered with anything: worth, the freedom of everyone. The continuation upon this path is, then, the responsibility of everyone, including the first jurists through their philosophical instruments; just as the arrest is attributable to those who eschew the subject or to those who, aware of certain injuries, justify them on the basis of contingent problems or to those who, worse yet, even if perceiving them, refrain from contradicting or opposing impervious and dark attempts to return to the past. And then, in a favourable sense, it is necessary to see all the legislative ${ }^{86}$ and

83 Marchegiani L. Il diritto sulla propria notorietà [The right over one's reputation]. In: Riv. dir. civ., Vol. 1, 2001, p. 191; Scognamiglio C. Il diritto all'utilizzazione economica del nome e dell'immagine delle persone celebri [The right to economic use of the name and image of famous people]. In: Dir. Inf., 1988, p. 1.

${ }^{84}$ First, see the judgment of 23 April 2003 of the United Sections of the Court of Auditors (in Resp. Civ. Prev., 2003, 1130), followed by the famous judgments of the Court of Cassation Nos. 7281, 7282 and 7283 of 12 May 2003 (with note Ziviz P. E poi non rimase nessuno [And then there was no one left]. In: Danno e resp., 2003 p. 713) and Nos. 8827 and 8828 of May 31, 2003 (with note Busnelli F. D. Chiaroscuri d'estate. La Corte di cassazione e il danno alla persona [Light shutters in summer. The Court of Cassation and personal injury]. In: Danno e resp., 2003 p. 816). To consolidate the changed orientation, the Constitutional Court intervened with sentence No. 233 of 11 July 2003 (with note by Ziviz P. Il nuovo volto dell'art. 2059 c.c. [The new face of Art. 2059 c.c.]. In: Resp. civ. prev., 2003, p. 1036) and the subsequent sentence of the Court of Cassation No. 12124 of 19 August 2003 (with note Ziviz P. Brevi riflessioni in materia di ingiustizia del danno non patrimoniale [Brief reflections on the injustice of non-pecuniary damage]. In: Resp. Civ. Prev., 2003, p. 1329). Finally, it should be noted that this orientation was also shared by the Cassation Court: on this point, cf. Ziviz P. Danno non patrimoniale: uno e trino [Non-pecuniary damage: one and three]. In: Resp. Civ. prev., 2004, p. 100.

85 Laconically stating that "Non-material patrimonial damage must only be compensated in cases determined by law". Talk about "a significant limit and often a foreclosure", Rescigno P. 1990, p. 8. On the issue, see more extensive considerations by Ferri G. B. Oggetto del diritto della personalità e danno non patrimoniale. In: Riv. dir. comm., 1984 [Subject of personality rights and non-pecuniary damage. In: Comm. Law Mag.], p. 154 ss. and di Majo A. Profili dei diritti della personalità [Profiles of personality rights]. In: Riv. trim. dir. proc. civ., Vol. I, 1962, 94 ss.

86 Among these, it is worth mentioning the Decree Law of 26 April 1993 No. 122 on "Urgent measures on racial, ethnic and religious discrimination" (in the Official Journal General Series No. 97 of 27 April 1993) and the Articles 43 and 443 of the Legislative Decree of 25 July 1998 No. 286 containing "Consolidated text of the provisions concerning immigration regulations and rules on the status of foreigners" (in Official Journal No. 191 of 18 August 1998, Ordinary Supplement No. 139). 
jurisprudential ${ }^{87}$ interventions that have followed each other over the years and are taking place to condemn any manifestly discriminatory and racist behaviour.

Hence, what is the remedy for the path to continue? In Bertrand Russell's "banquet speech" held in 1961 at the Nobel Retirement Ceremony, the philosopher voiced a conclusion that could be widely shared: "I would say that if my analysis is correct, what is needed for the world to be happy is mainly "intelligence". And this, all in all, is an optimistic conclusion, because intelligence is something that can be cultivated with proven educational methods" 88 .

A starting point, undoubtedly complex, yet, I hope, to be pursued.

\section{BIBLIOGRAPHY}

\section{Literature}

1. Alpa G. La cultura delle regole. Storia del diritto civile italiano [The culture of rules. History of Italian civil Law]. Roma-Bari, 2000.

2. Alpa G. Ugo Grozio. Qualche interrogativo di un profane [Ugo Grotius. Some questions of profane]. Bologna, 1998.

3. Alpa G., Ansaldo A. Le persone fisiche, Artt. 1-10 [Natural persons, Articles 1-10]. In: Il Codice Civile Commentario [The Civil Code Commentary]. Schlesinger P. (ed.), Milano, 1996.

4. Barassi L. Istituzioni di diritto civile [Institutions of civil law]. Milano, 1944.

5. Barbero D. Il sistema di diritto private [The system of private law]. $2^{\text {nd }}$ ed. a cura di Liserre e Floridia, 1993.

6. Battaglia F. v. Dichiarazioni dei diritti [Declaration of Rights]. In: Enc. Dir. XII, 1964, p. 409.

7. Bianca C. M. Diritto Civile, 1, la norma giuridica, i soggetti [Civil Law, 1, the legal rule, the subjects]. Milano, 2002.

8. Biondi B. Il diritto romano cristiano, II. Milano, 1952 [The Roman Christian Law].

87 Jurisprudence, both of merit and legitimacy, has several times intervened on the issue of discrimination and, in particular, in the hate speech and hate crimes sectors. Finally, see Court of Appeal sect. I - Brescia, 01/18/2019, No. 96. In: Foro it. 2019, 3, I, 1029; Cass. peNo., section V, March 23, 2018, No. 32028. In: Guide to law, 2018, pp. 33, 88; Court of Bologna, 7 March 2018. In: Foro it., 2018, 7-8, I, 2526. In civil matters, with particular reference to the right to report, see Court of Milano, Ord. June 13, 2019; Trib. Palmi, Ord. May 21, 2019; Court of Turin, Ord. May 28, 2019: all unpublished. The first Ordinance sentenced, for libel in the press, the journalistic newspaper 'Libero Quotidiano' to the compensation of damages in favour of a Cooperative mentioned in the article entitled "List of pimps that enriched themselves with the trafficking of black people"; the second Ordinance accepted the appeal of a Community citizen of Romanian nationality, holder of an "ENI card" with exemption code X01, ascertaining the right to access both to the specific exemption codes due to its peculiar pathologies, both to the free administration of health care providers and to the free administration of specific technological aid, all services re-entered in the LEA; finally, the third ordinance declared discriminatory the conduct of the Municipality of Turin for having denied the maternity allowance pursuant to Art. 74 Legislative Decree 151/2001 to non-EU town mothers holding permits for family reasons. Further measures on the subject of discrimination are available at https://www.asgi.it/banca-dati/?fwp_aree=giurisprudenza [last viewed May 10, 2019].

88 Padoan D. Per amore del mondo. Discorsi politici dei premi Nobel per la letteratura [For the love of the world. Political speeches of the Nobel Prize winners for literature]. Milan, 2018, pp. 77 and 95. 
9. Bobbio N. Giusnaturalismo e positivismo giuridico [Legal naturalism and legal positivism]. Milano, 1965.

10. Bocchini F., Quadri E. Diritto privato [Private law]. Torino, 2011.

11. Busnelli F. D. Chiaroscuri d'estate. La Corte di cassazione e il danno alla persona [Light shutters in summer. The Court of Cassation and personal injury]. In: Danno e resp. [Damage and resp.], 2003, p. 816.

12. Busnelli F.D. Il diritto delle persone [The Right of Person]. In: Cinquant'anni del codice civile, Atti del Convegno di Milano [Fifty years of the Civil Code, Proceedings of the Milan Conference], 4-6 giugno 1992, Milano, 1993.

13. Calasso F. Medioevo del diritto [Middle Ages of Law]. I. Milano, 1954.

14. Cavalli Sforza L. L., Cavalli Sforza F., Piazza A. Razza o pregiudizio? L'evoluzione dell'uomo fra natura e storia [Race or prejudice? The evolution of man between nature and history]. Milano, 1996.

15. De Cupis A. I diritti della personalità [The rights of the personality]. In: Trattato di dir. civ. comm. [Civil Law Treaty], a cura di Cicu A. e Messineo F., IV, t. 2. Milano, 1961.

16. De Frede D. Ricerche per la storia della stampa e la diffusione delle idee riformate nell'Italia del Cinquecento [Research for the history of the press and the dissemination of reformed ideas in Italy of $16^{\text {th }}$ century]. Napoli, 1985.

17. Degni F. Le persone fisiche e i diritti della personalità [The physical persons and the rights of the personality]. Torino, 1939.

18. Degni F. Trattato di diritto civile italiano, Le persone fisiche e i diritti della personalità [Italian Civil Law Treaty, Natural persons and personality rights]. Vol. II, t. 1, Torino, 1939.

19. Di Majo A. Profili dei diritti della personalità [Profiles of personality rights]. Riv. trim. dir. proc. civ., Vol. I, 1962, p. 94.

20. Falzone V., Palermo F., Cosentino F. La Costituzione della Repubblica italiana illustrata con i lavori preparatori [The Constitution of the Italian Republic illustrated with the preparatory work]. Milano, 1976.

21. Ferri G. B. Oggetto del diritto della personalità e danno non patrimoniale [Subject of personality rights and non-pecuniary damage]. Riv. dir. comm., 1984, p. 154.

22. Gangi C. Persone Fisiche e persone giuridiche [Physical persons and legal persons]. $2^{\text {nd }}$ ed., Milano, 1948.

23. Gaudemet J. Des'droits de l'homme 'ont-ils été reconnus dans l'Empire roman? [Have Human rights been recognized in the Roman Empire?]. In: Labeo, 1987, p. 7.

24. Gazzoni F. Manuale di diritto private [Manual of private law]. Napoli, 2000.

25. Giurati G. v. Fascismo [Fascism]. In: Nuovo Dig. It., V. Torino, 1938, p. 953.

26. Grossi P. Prima lezione di diritto [First law lesson]. Laterza, 2007.

27. Guarino A. Diritto privato Romano [Private Roman Law]. Jovene, 1992.

28. Irti N. Il salvagente della forma [The lifesaver of the form]. Roma-Bari, 2007.

29. Irti N. Nichilismo Giuridico [Legal Nihilism]. Roma-Bari, 2005.

30. Jellinek G. La dichiarazione dei diritti dell'uomo e del cittadino [The Declaration of Human and Citizen's Rights]. Bongiovanni G., Milano, 2002.

31. Kant I. Metaphysische Anfangsgrundeder Rechtleher [Metaphysical First Principles of the Doctrine of Right]. Italian translation: Primi principi metafisici della dottrina del diritto, a cura di Gonnelli F. Roma-Bari, 2005. 
32. Kant I. Vorlesunguber Ethik [Lectures on ethics]. Menzer P. (ed)., 1924. Italian translation: Lezioni di etica, a cura di Guerra A. Roma-Bari, 2004.

33. Kelsen H. Reine Rechtslehre. Einleitung in die rechtswissenchaftiche Problematik [Outlines of pure doctrine of law]. Italian translation: Lineamenti di dottrina pura del diritto, a cura di Treves R. Torino, 1952.

34. Ligi F. Contributo allo studio comparato dei diritti della personalità negli ordinamenti: tedesco, americano, francese e italiano [Contribution to the comparative study of personality rights in the legal systems: German, American, French and Italian]. In: Ann. dir. comp e di studi leg., Vol. III, 1956, p. 196.

35. Locke J. An Essay Concerning the True Original, Extent, and End of Civil Government [Italian translation Il Secondo Trattato sul Governo, by Magri T.]. Milano, 1998, p. 65.

36. Loiodice A. v. Informazione (diritto alla) [Information (Right of)]. In: Enc. Dir. XXI, 1971, p. 472.

37. Marcheggiani L. Il diritto sulla propria notorietà [The right over one's reputation]. In: Riv. dir. civ., Vol. I, 2001, p. 191.

38. Mazzacane A. v. Infamia (dir. rom.) [Infamy (Roman Law)]. In: Enc. Dir., XXI, 1971, p. 382.

39. Messineo F. Istituzioni di diritto civile [Institutions of civil law]. Milano, 1942.

40. Oestreich G. Geschichteder Menschenrecthe und Grundfreiheiten im UmriB [History of human rights and fundamental freedoms], 1968. Italian translation: Storia dei diritti umani e delle libertà fondamentali, a cura di Gozzi G., traduzione di Tommasi C. Roma-Bari, 2006.

41. Pacchioni G. Elementi di diritto civile [Elements of civil law]. Milano, 1943.

42. Padoan D. Per amore del mondo. Discorsi politici dei premi Nobel per la letteratura [For the love of the world. Political speeches of the Nobel Prize winners for literature]. Milano, 2018.

43. Pandolfelli G., Scarpello G., Stella Richter M., Dallari G. Codice Civile. Libro I, Illustrato con i lavori preparatori e con note di comment [Civil Code. Book I, Illustrated with the preparatory works and with commentary notes]. Milano, 1940.

44. Petrone C. L'essenza dello Stato Fascista [The essence of the Fascist State]. Roma, 1927.

45. Pinna A. Autodeterminazione e consenso: da regola per i trattamenti sanitari a principio generale [Self-determination and consent: as a rule for general principle healthcare treatments. In: contr. and business]. In: Contratto e imp. 2006, p. 589.

46. Pugliatti S. Gli istituti di diritto civile [Civil Law Institutes]. Vol. I., Milano, 1943.

47. Rescigno P. v. Personalità (diritti della) [Rights of personality]. In: Enc. Giur., XXIII. 1990, p. 6.

48. Resta G. Autonomia privata e diritti della personalità [Private autonomy and personality rights]. Jovene, 2005.

49. Rossi L. Breve storia della lingua italiana per parole [Brief history of the Italian language in words]. Loescher, v. razza, 2005.

50. Savigny Von F. Sistema del diritto romano attuale [Current Roman Law System]. Scialoja V. (ed.), III. Torino, 1886.

51. Scognamiglio C. Il diritto all'utilizzazione economica del nome e dell'immagine delle persone celebri [The right to economic use of the name and image of famous people]. In: Dir. Inf., 1988, p. 1. 
52. Stanzione P. Capacità, I) diritto privato. [Capacity, I) private law]. In: Enc. Giur., V. Roma, 1988, p. 4.

53. Windscheid B. Diritto delle Pandette [Right of the Pandects]. Prima trad. it. a cura di Fadda C. e Bensa P. E., Utet, 1902.

54. Zatti P. Persona giuridica e soggettività. Per una definizione del concetto di persona nel rapporto con la titolarità delle situazioni soggettive [Legal person and subjecticity. For a definition of the concept of person in relation to the ownership of subjective situations]. Cedam, 1975.

55. Zeno-Zencovich V. v. Personalità (diritti della). [Personality (rights of)]. Digesto, Sez. Civ., Vol. XIII, Utet, Torino, 1995.

56. Ziviz P. Brevi riflessioni in materia di ingiustizia del danno non patrimoniale [Brief reflections on the injustice of non-pecuniary damage]. In: Resp. civ. prev., 2003, p. 1329.

57. Ziviz P. E poi non rimase nessuno [And then there was no one left]. In: Danno e resp., 2003, p. 713.

58. Ziviz P. Danno non patrimoniale: uno e trino [Non-pecuniary damage: one and three]. In: Resp. civ. prev., 2004, p. 100.

59. Ziviz P. Il nuovo volto dell'art. 2059 c.c. [The new face of art. 2059 c.c.]. In: Resp. civ. prev., 2003, p. 1036.

\section{Legislative acts}

1. Royal Decree Law 17.11.1938, No. 1728. Official Journal, 29.11.1938, No. 264.

2. Royal Legislative Decree 20.01.1944, No. 25. Official Journal, special series, 09.02.1944, No. 5 .

3. Legislative lieutenant Decree 14.09.1944, No. 287. Official Journal, 09.11.1944, No. 79.

4. Decree Law 04.10.2018, No. 113. Official Journal, General Series, No. 231, 04.10.2018.

5. Law 01.12.2018, No. 132. Official Journal, General Series, No. 281, 02.12.2018.

6. Decree Law 25.07.1998, No. 286, available in the Official Gazette, General Series, No. 191, 18.08.1998, Ordinary Supplement No. 139.

7. Decree Act 14.06.2019, No. 53. Official Journal, 14.06.2019, General Series, No. 138.

8. Convention on the Law of the Sea, with annexes and final act, done at Montego Bay on 10 December 1982, ratified in Italy with the Law 02.12.1994, No. 689. The General Series No. 295, 19.12.1994, Ordinary Supplement No. 164.

9. Decree Law 26.04.1993, No. 122. Official Journal General Series No. 97, 27.04.1993.

10. Legislative Decree 25.07.1998, No. 286. Official Juornal No. 191, 18.08.1998, Ordinary Supplement, No. 139.

\section{Legal practice}

1. Judgment of Corte Costituzionale, No. 233, 11.07.2003. Resp. civ. prev., 2003, p. 1036.

2. Judgment of Court of Cassation No. 4890, 23.01.2019. Available at: www.asgi.it [last viewed May 10, 2019].

3. Judgment of Court of Cassation, section V, 23.03.2018, No. 32028. Guida al diritto, 2018, pp. 33, 88.

4. Judgment of Court of Cassation No. 12124, 19.08.2003. Resp. civ. prev., 2003, p. 1329. 
5. Judgment of Court of Cassation No. 7281, 7282 e 7283, 12.05.2003. Danno e resp., 2003, p. 713.

6. Judgment of Court of Cassation No. 8827 e 8828, 31.05.2003. Danno e resp., 2003, p. 816.

7. Judgment of Court of Cassation No. 2878, 29.01.1963. Gius. Civ., I, 1963, p. 2520.

8. Judgment of Court of Conti, S.U., 23.04.2003. Resp. civ. prev., 2003, p. 1130.

9. Judgment of Court of Appeal, Brescia, 01.18.2019, No. 96. Foro it. 3, I, 2019, p. 1029.

10. Judgment of Court of Appeal, Milano, 19.01.1971. Giur. It., I, sez. II, 1971, p. 1026.

11. Judgment of Court of Bologna, 07.03.2018, in Foro it., 7-8, I, 2018, p. 2526.

12. Judgment of Court of Milano, Ord., 13.05.2019. Available at: www.asgi.it [last viewed May 10, 2019].

13. Judgment of Trib. Palmi, Ord., 21.05.2019. Available at: www.asgi.it [last viewed May 10, 2019].

14. Judgment of Court of Turin, Ord. 28.052019. Available at: www.asgi.it [last viewed May 10, 2019]. 